\title{
Photosynthetic efficiency of tomato plants submitted to calcium silicate application
}

\section{Pablo Wenderson Ribeiro Coutinho', Márcia de Moraes Echer ${ }^{2}$, Vandeir Francisco Guimarães $^{2}$, Maria do Carmo Lana ${ }^{2}$, Adriano Mitio Inagaki ${ }^{3}$, Tauane Santos Brito ${ }^{2}$, Thatiane Nepomuceno Alves ${ }^{4}$}

\author{
${ }^{1}$ Eng. Agrônomo, Dr., Capitão Poço, Pará, Brasil. E-mail: pablowenderson@hotmail.com \\ ${ }^{2}$ Universidade Estadual do Oeste do Paraná, Campus Marechal Cândido Rondon, Marechal Cândido Rondon, Paraná, Brasil. E-mail: \\ mmecher@bol.com.br, vandeirfg@yahoo.com.br, maria.lana@unioeste.br, tauane-brito@hotmail.com \\ ${ }^{3}$ Pesquisador Associado da Corteva Agriscience, Palmas, Tocantins, Brasil. E-mail: mitioinagaki@gmail.com \\ ${ }^{4}$ Universidade Estadual Paulista, Campus de Botucatu, Botucatu, São Paulo, Brasil. E-mail: thatinepomuceno@hotmail.com \\ Received: 12/03/2020; Accepted: 27/07/2020.
}

\begin{abstract}
The objective was to evaluate the effect of calcium silicate on the chlorophyll content and gas exchange of two tomato hybrids. The design used was in randomized blocks in a $2 \times 5$ factorial scheme, with four replications. The first factor was composed of two tomato hybrids: Ivety and Natália, and the second factor was composed of five doses of calcium silicate $\left(0,150,300,450\right.$, and $\left.600 \mathrm{~kg} \mathrm{ha}^{-1}\right)$, applied to the substrate before planting the seedlings. Gas exchange: net $\mathrm{CO}_{2}$ assimilation rate $(A)$, leaf transpiration rate $(E)$, stomatal conductance $(g s)$, internal $\mathrm{CO}_{2}$ concentration $(\mathrm{Ci}$ ), water-use efficiency (WUE), intrinsic efficiency water use (iWUE), and instant carboxylation efficiency (ACi); SPAD index and the levels of chlorophylls a, b, and total were evaluated. The analyzes were performed in the stages of first flowering (17 days after transplanting - DAT), full flowering (58 DAT), and full fruiting (78 DAT). At 17 DAT, no difference was observed for gas exchange variables and photosynthetic pigments. The application of calcium silicate reduced gas exchange and photosynthetic pigments at 58 DAT. The hybrid Natália had the highest A, WUE, iWUE, and ACi at 78 DAT. However, the hybrid Ivety in the same growth stage, in full fruiting, was superior only for the internal concentration of $\mathrm{CO}_{2}$ and SPAD index, with no difference for photosynthetic pigments.
\end{abstract}

Keywords: fertilization, Solanum lycopersicum, gas exchange.

\section{Eficiência fotossintética de plantas de tomateiro submetidas à aplicação de silicato de cálcio}

\section{RESUMO}

O objetivo foi avaliar o efeito de silicato de cálcio nos teores de clorofilas e trocas gasosas de dois híbridos de tomateiro. $\mathrm{O}$ delineamento utilizado foi em blocos ao acaso em esquema fatorial $2 \times 5$, com quatro repetições. $\mathrm{O}$ primeiro fator contou com dois híbridos de tomateiro Ivety e Natália e o segundo fator com cinco doses de silicato de cálcio $\left(0,150,300,450\right.$ e $\left.600 \mathrm{~kg} \mathrm{ha}^{-1}\right)$, aplicados no substrato antes do plantio das mudas. As trocas gasosas: taxa de assimilação líquida de $\mathrm{CO}_{2}(A)$, taxa de transpiração foliar $(E)$, condutância estomática $(g s)$, concentração interna de $\mathrm{CO}_{2}(\mathrm{Ci})$, eficiência no uso da água (EUA), eficiência intrínseca no uso da água (EiUA) e eficiência instantânea de carboxilação (ACi); índice SPAD e os teores de clorofilas $a, b$ e total foram avaliados. As análises foram realizadas nos estádios de primeiro florescimento (17 dias após o transplantio - DAT), pleno florescimento (58 DAT) e plena frutificação (78 DAT). Aos 17 DAT não foi observada nenhuma diferença para as variáveis de trocas gasosas e pigmentos fotossintetizantes. A aplicação de silicato de cálcio reduziu as trocas gasosas e pigmentos fotossintetizantes aos 58 DAT. O híbrido Natália teve maior A, EUA, EiUA e ACi aos 78 DAT. Já o híbrido Ivety, no mesmo estádio de crescimento, em plena frutificação, foi superior apenas para concentração interna de $\mathrm{CO}_{2}$ e índice SPAD, não apresentando diferença para os pigmentos fotossintetizantes.

Palavras-chave: adubação, Solanum lycopersicum, trocas gasosas. 


\section{Introduction}

The tomato (Solanum lycopersicum L.) is a vegetable present in the daily diet of the population. Its cultivation is carried out worldwide, being highly demanding in technology and high doses of mineral fertilizers. The quantitative and qualitative characteristics of the tomato are genetically controlled and can be influenced by plant nutrition, environmental conditions, and post-harvest management (Dalastra et al., 2018). Thus, mineral elements can affect the morphology and physiology of photosynthetic organs (Rocha et al., 2019).

Among the macro and micronutrients, silicon ( $\mathrm{Si}$ ) has been studied in recent years since its presence in the cell wall of plant tissue results in benefits for plants. Although not acting directly on the main metabolic pathways of the plant, when present, this element can provide greater tolerance to biotic and abiotic stresses (Rodrigues et al., 2011). Silicon is absorbed in the form of orthosilicic (H4SiO4), being considered a beneficial nutrient for plants, since it accumulates in the cell wall, in the xylem vessels, and points of transpiration (Rodrigues et al., 2011). Thus, Si acts as a physical barrier, increasing the internal $\mathrm{CO}_{2}$ concentration, net $\mathrm{CO}_{2}$ assimilation rate, stomatal conductance, and water-use efficiency in tomato plants grown at different levels of salinity (Haghighi and Pessarakli, 2013).

Photosynthetic efficiency can be increased with the application of silicon, consequently, increasing the levels of chlorophyll in the leaves, in addition to reducing the transpiration process and improve the water-use efficiency (Murillo-Amador et al., 2007). In tomato, silicate fertilization increased productivity, with $60.80 \mathrm{t}$ $\mathrm{ha}^{-1}$ at a dose of $401 \mathrm{~kg} \mathrm{ha}^{-1}$ of $\mathrm{SiO}_{2}$ (Marodin et al., 2014).

The tomato crop is classified as a non-accumulator of silicon in the leaf, having low levels in the plant tissue, even with high levels of silicon in the soil (Lana et al., 2003). However, even with the lowest accumulation, silicon can increase productivity and post-harvest conservation time of tomatoes (Marodin et al., 2014).

It is essential, therefore, that more studies with the use of silicon in agriculture take place, which highlights the benefits of increasing tomato productivity, although the crop is not considered as an accumulator. Besides, more research is also needed on the physiological effect that silicon has. In this context, this study aimed to evaluate the impact of calcium silicate on the chlorophyll content and gas exchange of two tomato hybrids.

\section{Material and Methods}

The experiment was carried out from August to December 2017, in a protected environment, at the Protected Cultivation and Biological Control Station "Professor Dr. Mário César Lopes", at the Western
Paraná State University, in Marechal Cândido Rondon, Paraná. The region's climate is Cfa-type, humid subtropical mesothermal, with dry winter, welldistributed rains throughout the year, and hot summers, according to the Köppen classification (Alvares et al., 2013).

The experiment was installed under a galvanized iron structure with an arch-shaped ceiling, 7 x $30 \mathrm{~m}$, and 3.5 $\mathrm{m}$ in height, covered with low-density polyethylene film (150 $\mu \mathrm{m}$ thick), with transmissivity to solar radiation $80 \%$ and closed sides with white screen $40 \%$ shading. A data logger (HOMIS, model 494) was installed in a meteorological shelter at $1.20 \mathrm{~m}$ above ground level, in the center of the protected environment, to record the temperature and relative humidity data one-hour intervals.

The experimental design was a randomized block in a 2 x 5 factorial scheme, with four replications. The first factor was composed of two tomato hybrids (Ivety and Natália), and the second factor was composed of five doses of calcium silicate $(0,150,300,450$, and $600 \mathrm{~kg}$ $\left.\mathrm{ha}^{-1}\right)$. The Natália hybrid is of the long-life type with the rin gene. The hybrid Ivety does not have this gene in its genetic makeup, where the process of ripening and degrading the cell wall of the tomato is more accelerated, thus reducing the post-harvest life of this fruit.

The doses of calcium silicate were applied when filling the pots, which was made with a mixture of commercial substrate for vegetables and vermicompost in a 1:1 ratio. Calcium silicate has $20 \%$ silicon and $29 \%$ calcium in its composition. The chemical characterization of the mixture was: $\mathrm{P}=468.23 \mathrm{mg} \mathrm{dm}^{-3}$, $\mathrm{K}=2.19 \mathrm{cmol}_{\mathrm{c}} \mathrm{dm}^{-3}, \mathrm{Ca}^{2+}=13.72 \mathrm{cmol}_{\mathrm{c}} \mathrm{dm}^{-3}, \mathrm{Mg}^{2+}=$ $4.40 \mathrm{cmol}_{\mathrm{c}} \mathrm{dm}^{-3}, \mathrm{Cu}=1.40 \mathrm{mg} \mathrm{dm}^{-3}, \mathrm{Zn}=44 \mathrm{mg} \mathrm{dm}^{-3}$, $\mathrm{Mn}=136.58 \mathrm{mg} \mathrm{dm}^{-3}, \mathrm{Fe}=91.1 \mathrm{mg} \mathrm{dm}^{-3}, \mathrm{MO}=51.95 \mathrm{~g}$ $\mathrm{dm}^{-3}$, and $\mathrm{pH}=6.6$.

The $12 \mathrm{dm}^{3}$ pots were placed at a spacing of $1.20 \mathrm{~m}$ between rows and $0.5 \mathrm{~m}$ between plants, using one dish per pot. Each experimental plot was composed of four vessels, arranged in a single row.

The plants were conducted vertically on a single stem, using plastic tapes up to the height of approximately 1.90 $\mathrm{m}$ from the pot. Throughout the crop cycle, prunings were carried out to maintain one stem per plant; all were kept with six clusters, the apical bud being removed after the third leaf above the sixth cluster.

The irrigation was carried out via drip, four times a day, according to the crop needs, which was observed with the tensiometers installed in the pots, being applied around 1.0 to $2.5 \mathrm{~L}$ of water per day, maintaining the humidity of the soil above $80 \%$. A flexible tape with a flow rate of $1.6 \mathrm{~L} \mathrm{~h}^{-1}$ was used. Fertilization was carried out via fertigation, applying during the cycle: $3084 \mathrm{~g}$ of MAP, $3900 \mathrm{~g}$ of $\mathrm{MgSO}_{4}, 1824 \mathrm{~g}$ of $\mathrm{KNO}_{3}, 8148 \mathrm{~g}$ of $\mathrm{K}_{2} \mathrm{SO}_{4}, 7008 \mathrm{~g}$ of $\mathrm{Ca}\left(\mathrm{NO}_{3}\right)_{2}$, and $876 \mathrm{~g}$ of $\mathrm{H}_{3} \mathrm{BO}_{3}$, being 
also applied $320 \mathrm{~g}$ of micronutrients $(\mathrm{Mg} 3.8 \%, \mathrm{~S} 12 \%$, B 5\%, Cu 0.5\%, Fe 0.1\%, Mn 7\%, Mo 0.1\%, Zn 7\%).

The volume of the solution prepared for fertigation was $20 \mathrm{~L}$ per application, with 45 applications being carried out weekly, where 27 of them were in the stages of full flowering and beginning of fruiting, applying in this phase between $50-60 \%$ of the total amount of fertilizers with macro and micronutrient. In full fruiting, the first and second clusters were already being harvested when the rest of the fertilizers were applied, corresponding to a percentage between $40-50 \%$ of macro and micronutrients, with fertigation being carried out until one week before the last harvest.

Gas exchanges were measured three times during the crop cycle: at 17 days after transplanting (DAT) (first flowering), at 58 DAT (full flowering), and at 78 DAT (full fruiting), where the fruits of the first and the second cluster was in the ripening and harvesting period. The first evaluation was carried out on the fourth leaf, from the base to the apex of the plant, and the other two on the fourth leaf from the apex to the base located below the last cluster. The leaves used for the evaluation were fully expanded and with no apparent presence of lesions or symptoms of nutritional deficiency.

Gas exchange analyses were carried out with a portable infrared gas analyzer (Infra-red gas analyzer IRGA, model Li-6400XT, LI-COR INC., Nebraska, EUA). The net $\mathrm{CO} 2$ assimilation rate $\left(A-\mu \mathrm{mol} \mathrm{CO}_{2} \mathrm{~m}^{-2}\right.$ $\left.\mathrm{s}^{-1}\right)$, leaf transpiration rate $\left(E-\operatorname{mmol~} \mathrm{H}_{2} \mathrm{O} \mathrm{m} \mathrm{m}^{-2} \mathrm{~s}^{-1}\right)$, stomatal conductance $\left(g s-\mathrm{mol} \mathrm{H}_{2} \mathrm{O} \mathrm{m}^{-2} \mathrm{~s}^{-1}\right)$, and internal $\mathrm{CO}_{2}$ concentration $\left(\mathrm{Ci}-\mu \mathrm{mol} \mathrm{CO}_{2}\right.$ mol air-1) were evaluated. Water efficiency was also calculated (WUE $\mu \mathrm{mol} \mathrm{CO}_{2} \mathrm{~m}^{-2} \mathrm{~s}^{-1} / \mathrm{mol} \mathrm{H}_{2} \mathrm{O} \mathrm{m} \mathrm{m}^{-2} \mathrm{~s}^{-1}$ ), intrinsic water-use efficiency (iWUE - $\mu \mathrm{mol} \mathrm{CO}_{2} \mathrm{~m}^{-2} \mathrm{~s}^{-1} / \mathrm{mol} \mathrm{H}_{2} \mathrm{O} \mathrm{m} \mathrm{m}^{-2} \mathrm{~s}^{-1}$ ), and instant carboxylation efficiency $\left(\mathrm{ACi}-\mu \mathrm{mol} \mathrm{CO} \mathrm{CO}^{-}\right.$ $2 \mathrm{~s}^{-1} / \mu \mathrm{mol} \mathrm{CO}_{2}$ mol air $\left.{ }^{-1}\right)$. The measurements were performed on days without cloudiness, from 9:00 am to 11:00 am, under the saturated artificial light of 1200 $\mu \mathrm{mol} \mathrm{m} \mathrm{m}^{-2} \mathrm{~s}^{-1}$ and $\mathrm{CO}_{2}$ concentration at $380 \mu \mathrm{mol}$.
The SPAD index was performed on the same leaves as the gas exchanges were measured. It was obtained with the aid of the portable SPAD 502 Plus Daminolta meter, with three measurements per leaf. Subsequently, these leaves were collected to determine the levels of pigments, such as chlorophyll a, b, and total (Sims and Gamon, 2002). Pigment concentrations were estimated according to Lichtenthaler (1987).

The data were tested for normality of variances by the Lilliefors test and then subjected to analysis of variance by the F-test and regression at $5 \%$ probability. The correlation analysis (Pearson) between the parameters was performed using the GENES software (Cruz, 2013).

\section{Results and Discussion}

The recordings of temperature, relative humidity, and radiation were carried out throughout the experimental period (Figure 1). The temperature and radiation during the gas exchange measurement schedule showed temperature fluctuations from 34 to $39{ }^{\circ} \mathrm{C}$ and solar radiation of $16.22 \mathrm{MJ} \mathrm{m}^{-2} \mathrm{day}^{-1}$ in the first assessment, at 17 DAT. At 58 DAT, the temperature fluctuated from 27 to $31{ }^{\circ} \mathrm{C}$ with solar radiation of $23.54 \mathrm{MJ} \mathrm{m}^{-2}$ day $^{-1}$; at 78 DAT, the temperature was 32 to $33{ }^{\circ} \mathrm{C}$ with solar radiation of $24.05 \mathrm{MJ} \mathrm{m}^{-2}$ day $^{-1}$.

For each tomato hybrid and phase of the cycle, there is an optimal temperature; these climatic elements are within the recommended for the crop, although temperatures above $35{ }^{\circ} \mathrm{C}$ have been observed only in the first crop stage. The ideal temperature for the crop is above $10{ }^{\circ} \mathrm{C}$ and below $35^{\circ} \mathrm{C}$ (Dalastra et al., 2018).

There was no interaction between hybrids and calcium silicate doses for any phenological stage in any gas exchange variable. Thus, the factors were evaluated separately, where a difference was observed between doses only at the flowering stage, at $58 \mathrm{DAT}$, for $A, g s$, $E$, and ACi (Figure 2).
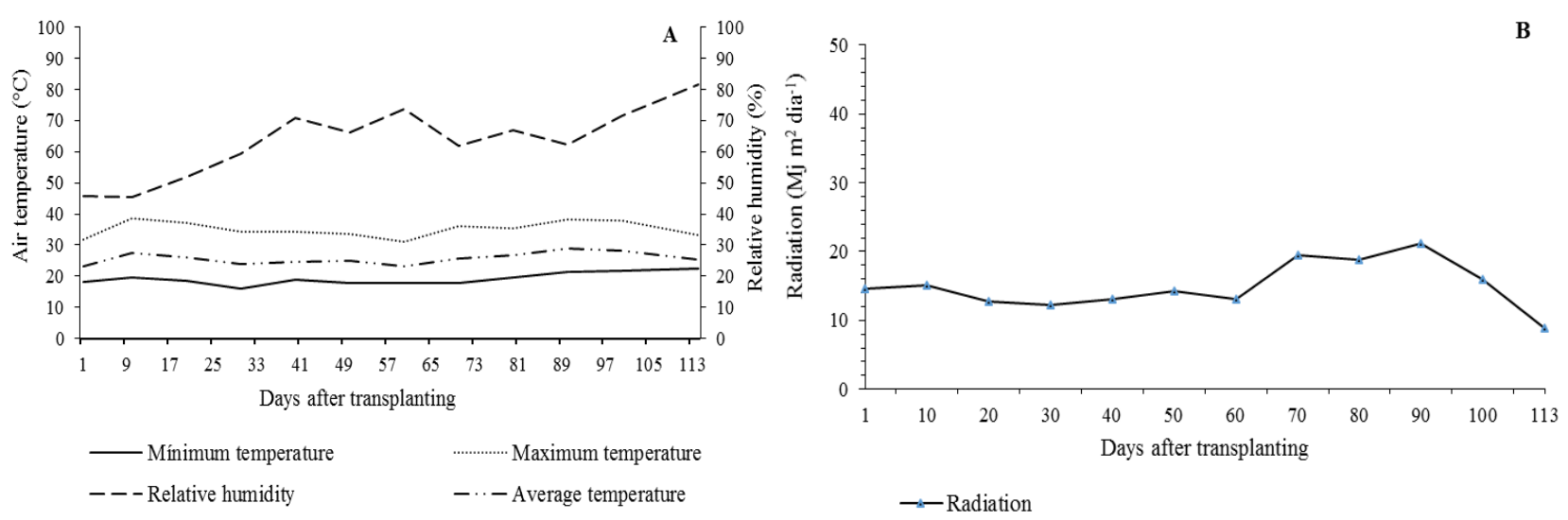

Figure 1. Average, minimum, and maximum values of air temperature, and average relative air humidity (A), and solar radiation (B), during tomato cultivation in a protected environment. 

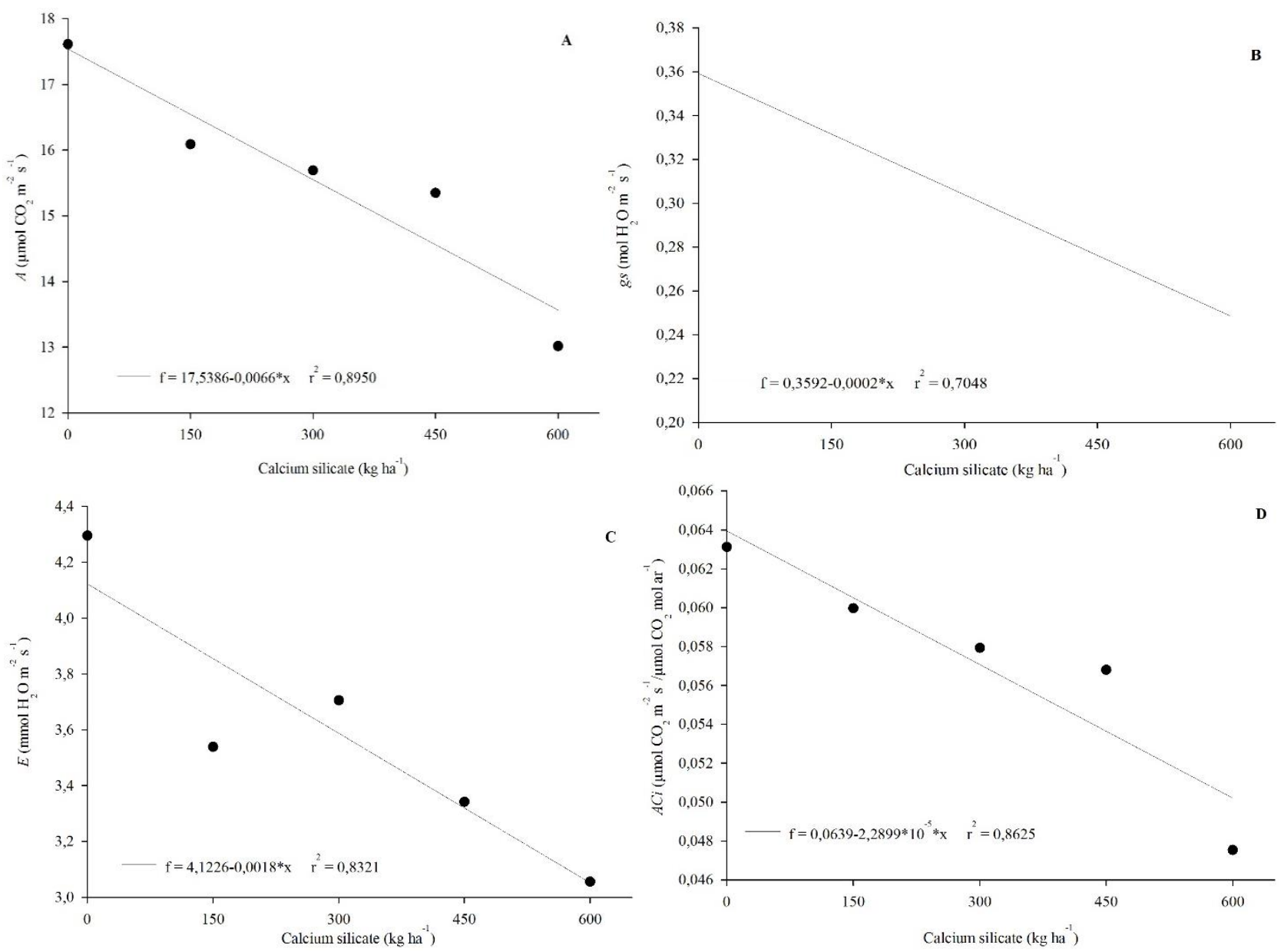

Figure 2. $\mathrm{CO}_{2}$ assimilation rate $(A)$, stomatal conductance $(g s)$, leaf transpiration $(E)$, and instant carboxylation efficiency (ACi) of tomato at $58 \mathrm{DAT}$ according to the calcium silicate doses.

$A, g s, C i, E$, WUE, iWUE, and ACi were not affected by the factors studied at 17 DAT (Table 1). The $A$ was reduced with the increase of calcium silicate doses at 58 DAT (Figure 2A), and at this stage, the plant was in full bloom with the first formed clusters. This difference only at this stage may have occurred due to the hormonal issue of the plant because, in this period, it was preparing for fruiting, where the accumulation of calcium silicate regulated the hormone that stimulates the formation of fruits; this same result was observed in the pepper crop (Abdelaal et al., 2020).

The hormonal imbalance in the plant decreases the redistribution of photoassimilates to flowers and fruits, thus providing changes in the number of fruits and unbalanced growth of the plant in the successive stage of development, changing the size and shape of the fruit (Dalastra et al., 2018).

The $A$, WUE, iWUE, and ACi of the hybrid Natália were higher at 78 DAT (Table 1). The lack of effect of calcium silicate at 78 DAT may have occurred due to the translocation of the photoassimilates to the main drains of the plant at this time, which are the tomato fruits (Marodin et al., 2014). Changes in $A$ during the growth and development stage of the crop also occur in response to light, temperature, and nutritional status, as this plays an important role in plant adaptations and contributes to them being productive (Echer et al., 2020).

The Natália hybrid, in the period of full fruiting, at 78 DAT, presents the highest $A$, due to the greater amount of $\mathrm{CO}_{2}$ in the sub-stomatal chamber, thus having more substrate to perform photosynthesis, that is, all the light that the antenna complex received was sent to the electron transport chain to supply energy to the Calvin cycle, having substrate to transform into sugar in the next step (Table 1). Considering that the two hybrids have $\mathrm{C} 3$ metabolism, without $\mathrm{CO}_{2}$ concentration mechanisms, these differences must be related to the greater efficiency of using ATP and NADPH in the Calvin cycle (Ehleringer and Björkman, 1977; Kirschbaum, 1994).

The $A$ correlated with all other gas exchange variables at 78 DAT (Table 2). This correction confirms the results obtained in a study with water ratio in bell peppers for one day, where the authors stated that $A$ and $C i$ are variables that correlate because the higher concentration of $\mathrm{CO}_{2}$ in the leaves is the result of greater assimilation in plants (Jadoski et al., 2005).

Although high temperatures occurred in some days (Figure 1), this did not affect the plants physiologically. 
Gas exchanges may vary depending on the phenological stage of the crop, between cultivars and hybrids (Driever et al., 2014), by management conditions (Zeist et al., 2018), and depending on climatic conditions at the time of assessment (Dalastra et al., 2018).

The $g s$ decreased with the increase of calcium silicate doses at the full flowering stage, at 58 DAT (Figure 2B), with no significant effect for this variable in the other evaluations. This reduction may have occurred due to some momentary stress, such as an increase in temperature, as $g s$ is a punctual measure and will determine the number of stomata opened at the time of reading (Rocha et al., 2019).

The reduction of $g s$ according to the calcium silicate doses may have occurred due to the accumulation of ions in the cell wall (Parveen and Ashraf, 2010), although tomato is not a silicon accumulator culture in the leaf, as this element has been translocated to the formation of fruits, which are the main drains (Haghighi and Pessarakli, 2013; Marodin et al., 2014). When this occurs, the $g s$ limits the flow of $\mathrm{CO}_{2}$ in the leaves, which causes a reduction in $A$; this same event was observed in a study with the effect of drought and saline stress on melon genotypes (Kusvuran, 2012).

The $g s$ had a positive correlation with $C i$ and $E$, which are characteristics that can cause an increase or decrease in photosynthetic yield (Ferraz et al., 2012). Presenting a negative correlation for WUE and iWUE (Table 2); this occurs due to the limitation of stomatal opening and closing, which controls the loss of water through transpiration, which may be limited to $A$ (Adams et al., 2016). $E$ is the main mechanism that plants have to protect themselves from excessive radiation and regulate leaf temperature, depending on the stoma opening and closing mechanism (Taiz et al., 2017).

The $E$ had a difference due to the calcium silicate doses only at 58 DAT (Figure 2C), with a reduction in the $E$ with increasing doses. Leaf $E$ correlated positively with ACi and, as observed for $g s$, negatively correlated with WUE and iWUE (Table 2). This reduction in water loss to the growing environment in the form of steam, demonstrated at stage 58 DAT, is regulated by the activity of the guard cells (Parveen and Ashraf, 2010; Haghighi and Pessarakli, 2013).

Table 1. $\mathrm{CO} 2$ assimilation rate $(A)$, stomatal conductance $(\mathrm{gs})$, internal $\mathrm{CO}_{2}$ concentration $(\mathrm{Ci})$, leaf transpiration $(E)$, water-use efficiency (WUE), intrinsic water-use efficiency (iWUE), and instant carboxylation efficiency (ACi) in two tomato hybrids, at 17, 58 and 78 days after transplanting (DAT).

\begin{tabular}{|c|c|c|c|c|}
\hline \multicolumn{5}{|c|}{$* * 17 \mathrm{DAT}$} \\
\hline \multirow{2}{*}{ Hybrids } & $A$ & $g s$ & $C i$ & $E$ \\
\hline & $\mu \mathrm{mol} \mathrm{CO} 2 \mathrm{~m}^{-2} \mathrm{~s}^{-1}$ & $\mathrm{~mol} \mathrm{H}_{2} \mathrm{O} \mathrm{m}^{-2} \mathrm{~s}^{-1}$ & $\mu \mathrm{mol} \mathrm{CO} 2 \mathrm{~mol} \mathrm{ar}^{-1}$ & $\mathrm{mmol} \mathrm{H}_{2} \mathrm{O} \mathrm{m}^{-2} \mathrm{~s}^{-1}$ \\
\hline Ivety & 27.17 & 0.32 & 232.08 & 7.76 \\
\hline Natália & 27.21 & 0.31 & 225.95 & 8.17 \\
\hline $\mathrm{CV} \%$ & 14.37 & 24.86 & 7.52 & 16.26 \\
\hline ð & 0.87 & 0.02 & 3.85 & 0.29 \\
\hline \multirow{2}{*}{ Hybrids } & WUE & \multicolumn{2}{|c|}{ Iwue } & $\mathrm{ACi}$ \\
\hline & 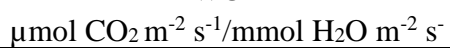 & \multicolumn{2}{|c|}{$\mu \mathrm{mol} \mathrm{CO} \mathrm{Cm}_{2} \mathrm{~m}^{-1} / \mathrm{mol} \mathrm{H}_{2} \mathrm{O} \mathrm{m}^{-2} \mathrm{~s}^{-1}$} & $\mu \mathrm{mol} \mathrm{CO} 2 \mathrm{~m}^{-2} \mathrm{~s}^{-1} / \mu \mathrm{mol} \mathrm{CO} 2 \mathrm{~mol} \mathrm{ar}^{-1}$ \\
\hline Ivety & 3.51 & \multicolumn{2}{|c|}{86.27} & 0.12 \\
\hline Natália & 3.37 & \multicolumn{2}{|c|}{89.59} & 0.12 \\
\hline $\mathrm{CV} \%$ & 7.31 & \multicolumn{2}{|c|}{12.66} & 13.43 \\
\hline ð & 0.06 & \multicolumn{2}{|c|}{2.49} & 0.00 \\
\hline \multicolumn{5}{|c|}{58 DAT } \\
\hline \multirow{2}{*}{ Hybrids } & $C i$ & \multicolumn{2}{|c|}{ WUE } & iWUE \\
\hline & $\mu \mathrm{mol} \mathrm{CO} 2 \mathrm{~mol} \mathrm{ar}^{-1}$ & \multicolumn{2}{|c|}{$\mu \mathrm{mol} \mathrm{CO} 2 \mathrm{~m}^{-2} \mathrm{~s}^{-1} / \mathrm{mmol} \mathrm{H}_{2} \mathrm{O} \mathrm{m}^{-2} \mathrm{~s}^{-1}$} & $\mu \mathrm{mol} \mathrm{CO} \mathrm{Cm}^{-2} \mathrm{~s}^{-1} / \mathrm{mol} \mathrm{H}_{2} \mathrm{O} \mathrm{m}^{-2} \mathrm{~s}^{-1}$ \\
\hline Ivety & 275.12 & \multicolumn{2}{|c|}{4.47} & 53.92 \\
\hline Natália & 272.71 & \multicolumn{2}{|c|}{4.45} & 54.53 \\
\hline $\mathrm{CV} \%$ & 6.90 & \multicolumn{2}{|c|}{14.81} & 22.22 \\
\hline ð & 4.23 & \multicolumn{2}{|c|}{0.15} & 2.69 \\
\hline \multicolumn{5}{|c|}{$78 \mathrm{DAT}$} \\
\hline \multirow[t]{2}{*}{ Hybrids } & $A$ & $g_{s}$ & $C_{i}$ & $E$ \\
\hline & $\mu \mathrm{mol} \mathrm{CO} 2 \mathrm{~m}^{-2} \mathrm{~s}^{-1}$ & $\mathrm{~mol} \mathrm{H}_{2} \mathrm{O} \mathrm{m}^{-2} \mathrm{~s}^{-1}$ & $\mu \mathrm{mol} \mathrm{CO} 2 \mathrm{~mol} \mathrm{ar}^{-1}$ & $\mathrm{mmol} \mathrm{H}_{2} \mathrm{O} \mathrm{m}^{-2} \mathrm{~s}^{-1}$ \\
\hline Ivety & $24.58 \mathrm{~b}^{*}$ & 0.37 & $293.61 \mathrm{a}$ & 3.05 \\
\hline Natália & $31.51 \mathrm{a}$ & 0.39 & $269.39 \mathrm{~b}$ & 3.41 \\
\hline $\mathrm{CV} \%$ & 20.32 & 19.15 & 9.05 & 17.42 \\
\hline ð & 1.27 & 0.02 & 5.69 & 0.13 \\
\hline \multirow{2}{*}{ Hybrids } & WUE & \multicolumn{2}{|c|}{ iWUE } & $\mathrm{ACi}$ \\
\hline & $\mu \mathrm{mol} \mathrm{CO} 2 \mathrm{~m}^{-2} \mathrm{~s}^{-1} / \mathrm{mmol} \mathrm{H}_{2} \mathrm{O} \mathrm{m}^{-2} \mathrm{~s}^{-}$ & \multicolumn{2}{|c|}{$\mu \mathrm{mol} \mathrm{CO} \mathrm{CO}_{2} \mathrm{~m}^{-1} / \mathrm{mol} \mathrm{H}_{2} \mathrm{O} \mathrm{m}^{-2} \mathrm{~s}^{-1}$} & $\mu \mathrm{mol} \mathrm{CO} 2 \mathrm{~m}^{-2} \mathrm{~s}^{-1} / \mu \mathrm{mol} \mathrm{CO} 2 \mathrm{~mol} \mathrm{ar}^{-1}$ \\
\hline Ivety & $8.34 \mathrm{~b}$ & \multicolumn{2}{|c|}{$68.70 \mathrm{~b}$} & $0.09 \mathrm{~b}$ \\
\hline Natália & $9.47 \mathrm{a}$ & \multicolumn{2}{|c|}{$81.13 \mathrm{a}$} & $0.12 \mathrm{a}$ \\
\hline $\mathrm{CV} \%$ & 18.70 & \multicolumn{2}{|c|}{19.43} & 27.24 \\
\hline ð & 0.37 & \multicolumn{2}{|c|}{3.26} & 0.01 \\
\hline
\end{tabular}

*Significant at $5 \%$ probability by the $\mathrm{F}$ test. ** Phenological stages. 
Table 2. Pearson correlation coefficients between gas exchange variables $\left(\mathrm{CO}_{2}\right.$ assimilation rate $(A)$, stomatal conductance $(g s)$, internal $\mathrm{CO}_{2}$ concentration $(\mathrm{Ci})$, leaf transpiration $(E)$, water-use efficiency (WUE), intrinsic water-use efficiency (iWUE), instant carboxylation efficiency (ACi), chlorophyll a, b, total (CL $a, C L b$, and $C L T)$ and SPAD in tomato hybrids at 17, 58, and 78 days after transplanting (DAT). Values from the means of four replications of two tomato hybrids submitted to calcium silicate doses application.

\begin{tabular}{|c|c|c|c|c|c|c|c|c|c|c|c|}
\hline & DAT & A & $g s$ & $C_{i}$ & $E$ & WUE & iWUE & $\mathrm{ACi}$ & $C L a$ & $C L b$ & $C L T$ \\
\hline \multirow{3}{*}{$g s$} & 17 & $77.39 * *$ & & & & & & & & & \\
\hline & 58 & $70.12 * *$ & & & & & & & & & \\
\hline & 78 & $50.01 * *$ & & & & & & & & & \\
\hline \multirow{3}{*}{$\mathrm{Ci}$} & 17 & $2.62^{\mathrm{ns}}$ & $56.58 * *$ & & & & & & & & \\
\hline & 58 & $5.08^{\mathrm{ns}}$ & $63.54 * *$ & & & & & & & & \\
\hline & 78 & $73.00 * *$ & $19.96^{\mathrm{ns}}$ & & & & & & & & \\
\hline \multirow{3}{*}{$E$} & 17 & $89.03 * *$ & $84.24 * *$ & $17.55^{\mathrm{ns}}$ & & & & & & & \\
\hline & 58 & $75.08 * *$ & $87.56^{* *}$ & $40.34 * *$ & & & & & & & \\
\hline & 78 & $49.69 * *$ & $84.79 * *$ & $4.02^{\text {ns }}$ & & & & & & & \\
\hline \multirow{3}{*}{ WUE } & 17 & $1.95^{\mathrm{ns}}$ & $-30.03^{\mathrm{ns}}$ & $-45.85^{* *}$ & $-42.75 * *$ & & & & & & \\
\hline & 58 & $-3.62^{\mathrm{ns}}$ & $-53.73 * *$ & $-69.54 * *$ & $-66.84 * *$ & & & & & & \\
\hline & 78 & $48.21 * *$ & $-31.41 *$ & $-73.47 * *$ & $-50.35^{* *}$ & & & & & & \\
\hline \multirow{3}{*}{ iWUE } & 17 & $-12.99^{\mathrm{ns}}$ & $-68.16 * *$ & $-98.70 * *$ & $-32.59 *$ & $48.20 * *$ & & & & & \\
\hline & 58 & $-19.90^{\mathrm{ns}}$ & $-80.14 * *$ & $-96.49 * *$ & $-61.78 * *$ & $74.22 * *$ & & & & & \\
\hline & 78 & $65.07 * *$ & $-30.89 *$ & $-99.08 * *$ & $-16.54^{\mathrm{ns}}$ & $78.39 * *$ & & & & & \\
\hline \multirow{3}{*}{$\mathrm{ACi}$} & 17 & $82.93 * *$ & $32.19 *$ & $-56.73 * *$ & $62.07 * *$ & $28.29^{\mathrm{ns}}$ & $43.41 * *$ & & & & \\
\hline & 58 & $92.49 * *$ & $39.42 *$ & $-41.98 * *$ & $52.77 * *$ & $22.35^{\mathrm{ns}}$ & $18.05^{\mathrm{ns}}$ & & & & \\
\hline & 78 & $97.06^{* *}$ & $30.15^{\text {ns }}$ & $-86.01 * *$ & $35.18^{*}$ & $58.92 * *$ & $79.90 * *$ & & & & \\
\hline \multirow{3}{*}{$C L a$} & 17 & $-33.72 *$ & $-31.82 *$ & $-4.21^{\mathrm{ns}}$ & $-35.45^{*}$ & $13.24^{\mathrm{ns}}$ & $9.79^{\mathrm{ns}}$ & $-25.81^{\mathrm{ns}}$ & & & \\
\hline & 58 & $33.69 *$ & $12.90^{\mathrm{ns}}$ & $-8.01^{\mathrm{ns}}$ & $18.93^{\mathrm{ns}}$ & $4.28^{\mathrm{ns}}$ & $-0.16^{\mathrm{ns}}$ & $35.46^{*}$ & & & \\
\hline & 78 & $-28.45^{\mathrm{ns}}$ & $-28.69^{\mathrm{ns}}$ & $9.66^{\mathrm{ns}}$ & $-18.37^{\mathrm{ns}}$ & $-10.35^{\text {ns }}$ & $-6.84^{\mathrm{ns}}$ & $-24.95^{\mathrm{ns}}$ & & & \\
\hline \multirow{3}{*}{$C L b$} & 17 & $-33.00 *$ & $-18.71^{\mathrm{ns}}$ & $18.95^{\text {ns }}$ & $-37.17 *$ & $20.06^{\mathrm{ns}}$ & $-12.14^{\mathrm{ns}}$ & $-36.43^{*}$ & $41.69 * *$ & & \\
\hline & 58 & $18.97^{\mathrm{ns}}$ & $-8.10^{\mathrm{ns}}$ & $-25.48^{\mathrm{ns}}$ & $0.87^{\mathrm{ns}}$ & $14.53^{\mathrm{ns}}$ & $20.34^{\mathrm{ns}}$ & $28.93^{\mathrm{ns}}$ & $88.94 * *$ & & \\
\hline & 78 & $-33.09 *$ & $-30.51^{\mathrm{ns}}$ & $13.65^{\mathrm{ns}}$ & $-26.52^{\mathrm{ns}}$ & $-7.18^{\mathrm{ns}}$ & $-10.17^{\mathrm{ns}}$ & $-27.37^{\mathrm{ns}}$ & $76.89 * *$ & & \\
\hline \multirow{3}{*}{$C L T$} & 17 & $-39.35^{\mathrm{ns}}$ & $-31.43^{*}$ & $5.68^{\mathrm{ns}}$ & $-42.51 * *$ & $18.71^{\mathrm{ns}}$ & $1.46^{\mathrm{ns}}$ & $-35.26^{*}$ & $90.86^{* *}$ & $75.85 * *$ & \\
\hline & 58 & $30.11^{\mathrm{ns}}$ & $6.98^{\mathrm{ns}}$ & $-13.37^{\mathrm{ns}}$ & $14.02^{\mathrm{ns}}$ & $7.42^{\mathrm{ns}}$ & $5.90^{\mathrm{ns}}$ & $34.35^{*}$ & $99.08 * *$ & $94.31 * *$ & \\
\hline & 78 & $-31.79 *$ & $-30.99 *$ & $11.69^{\mathrm{ns}}$ & $-22.42^{\mathrm{ns}}$ & $-9.78^{\mathrm{ns}}$ & $-8.46^{\mathrm{ns}}$ & $-27.27^{\mathrm{ns}}$ & $97.17 * *$ & $89.82 * *$ & \\
\hline \multirow{3}{*}{ SPAD } & 17 & $-8.76^{\mathrm{ns}}$ & $-7.90^{\mathrm{ns}}$ & $-12.51^{\mathrm{ns}}$ & $-2.01^{\mathrm{ns}}$ & $-5.69^{\text {ns }}$ & $13.70^{\mathrm{ns}}$ & $-1.88^{\mathrm{ns}}$ & $18.79^{\mathrm{ns}}$ & $-1.45^{\mathrm{ns}}$ & $12.82^{\mathrm{ns}}$ \\
\hline & 58 & $20.00^{\mathrm{ns}}$ & $4.46^{\mathrm{ns}}$ & $-18.46^{\mathrm{ns}}$ & $15.03^{\mathrm{ns}}$ & $-1.22^{\mathrm{ns}}$ & $10.47^{\mathrm{ns}}$ & $27.01^{\mathrm{ns}}$ & $17.38^{\mathrm{ns}}$ & $20.89^{\text {ns }}$ & $18.82^{\mathrm{ns}}$ \\
\hline & 78 & $29.15^{\mathrm{ns}}$ & $23.80^{\text {ns }}$ & $-12.66^{\mathrm{ns}}$ & $18.81^{\text {ns }}$ & $10.35^{\mathrm{ns}}$ & $10.08^{\mathrm{ns}}$ & $25.97^{\mathrm{ns}}$ & $-5.40^{\text {ns }}$ & $6.92^{\mathrm{ns}}$ & $-1.16^{\mathrm{ns}}$ \\
\hline
\end{tabular}

* - significant at $1 \%$ probability by the t-test; $* *$ - significant at $5 \%$ probability by the t-test; ${ }^{\text {ns }}$ - not significant at $5 \%$ probability by the t-test.

The plants that received the highest doses of calcium silicate had lower $E$, a fact that happened due to the change in the structure of the leaf organelles, which activated the defense system of the plants and the mitigation of specific ions, thus improving the water status due to the lowest loss of water vapor. These results agree with the controls of a study that worked with tomato plants grown at different levels of salinity, which obtained around $3 \mathrm{mmol} \mathrm{m}^{-2} \mathrm{~s}^{-1}$ (Haghighi and Pessarakli, 2013).

$C i$ had no difference due to the applied calcium silicate doses, having difference only between the hybrids in the full fruiting stage (78 DAT), where Ivety was superior (Table 1). It was also observed that $\mathrm{Ci}$ presented a negative correlation with WUE, iWUE, and ACi (Table 2), which influenced the stoma opening and closing, the entry and exit of $\mathrm{CO}_{2}$, the loss of water, and consequently, its fixation in the formation of new carbohydrates. Lower $\mathrm{Ci}$ values stimulate stoma closure with a consequent decrease in the rate of $\mathrm{CO}_{2}$ assimilation (Rocha et al., 2019).
The WUE and iWUE were not influenced by the calcium silicate doses, with a difference between the hybrids only in the full fruiting stage (78 DAT), where the Natália hybrid was superior (Table 1). In this study, water demand was met, and it is known that silicon, when present in the leaf cell wall, can increase the WUE. This fact is confirmed in a study carried out with pumpkin on saline stress (Siddiqui et al., 2014). The WUE had a positive correlation with iWUE and $\mathrm{ACi}$, thus demonstrating that stomatal opening is efficient for these variables, since it presented a $\mathrm{CO}_{2}$ fixation in the leaf mesophyll without providing $\mathrm{H}_{2} \mathrm{O}$ loss (Table 2).

ACi was influenced by calcium silicate doses in the full bloom stage at 58 DAT (Figure 2D), with a reduction due to the increase in Si doses. At 78 DAT, a difference between hybrids was observed, with 'Natália' being superior as ACi (Table 1). The reduction in ACi at 58 DAT may be the result of $\mathrm{Ci}$, as this may provide a reduction in $A$ due to the decrease in $\mathrm{CO}_{2}$ concentration for the enzyme Rubisco (ribulose-1,5-bisphosphate carboxylase-oxygenase), reducing its efficiency in 
uptake and incorporation into the Calvin cycle (Ehleringer and Björkman, 1977; Kirschbaum, 1994). These results, obtained at different phenological stages in the two hybrids due to the calcium silicate, may change due to the climatic conditions of each cultivation site, besides the stage in which the crop is found and among other factors.

For photosynthetic pigments, no interaction was observed between tomato hybrids and calcium silicate doses for any phenological stage, and the factors were studied in isolation. As the effects of calcium silicate doses on leaf contents of chlorophyll a, b, and total, only at 58 DAT, a significant difference was observed (Figure 3).

The content of total chlorophyll had the same behavior as chlorophyll a and $b$, with no difference between hybrids at any phenological stage in which they were measured, with only a reduction in the total chlorophyll content due to the increase of calcium silicate doses at 58 DAT (Figure 3C).
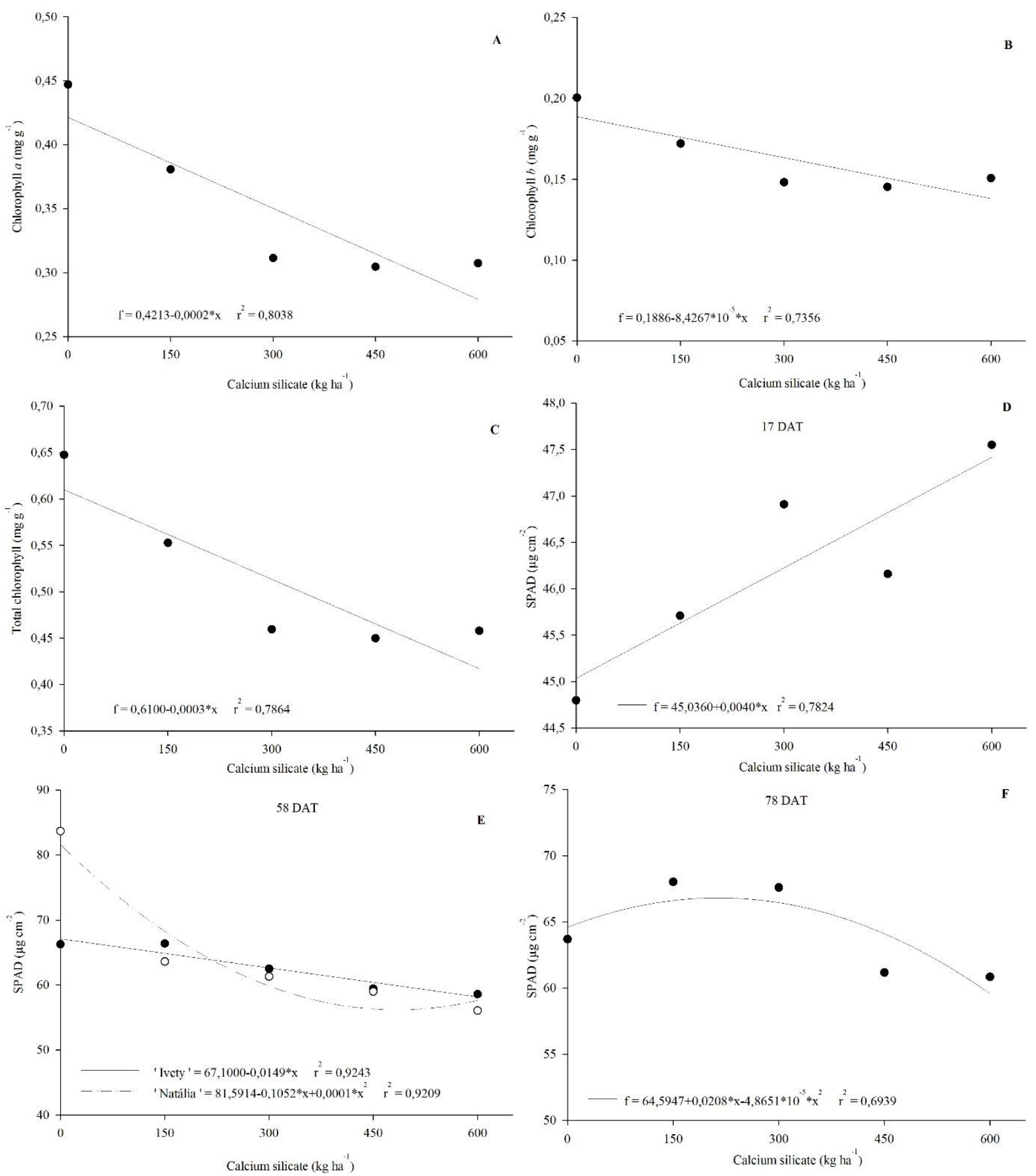

Figure 3. Content of chlorophyll a, b, and total at 58 DAT and SPAD index at 17, 58 and 78 DAT of tomato plants according to the calcium silicate doses. 
The chlorophyll $a$ content did not differ between hybrids at any phenological stage (Table 3). A decreasing linear adjustment was observed at 58 DAT, with a reduction in content due to the increase of calcium silicate doses (Figure 3A). This photosynthetic pigment correlated only with the levels of chlorophyll $b$ and total (Table 2). Chlorophyll a is a very important pigment in the plant, as it is present in the photochemical phase, and the other pigments help in absorbing light and transferring energy to the reaction centers (Taiz et al., 2017).

Chlorophyll $b$ had the same behavior as chlorophyll a, with a difference for leaf contents only at the flowering stage at $58 \mathrm{DAT}$, with a reduction of the content of this pigment due to the increase in calcium silicate doses (Figure 3B). However, despite similar results, the contents of chlorophyll $a$ and $b$ are presented in different proportions. This is because the proportion of chlorophyll $a$ and $b$ is $3: 1$, as a rule, but varies according to the species, leaf age, and location of the leaf and canopy of the plant (Taiz et al., 2017). The leaves collected to carry out the evaluations of pigment contents were the same as the gas exchange analyses, with the tip of the leaf blade being removed.

Chlorophylls are pigments responsible for converting light radiation into energy, in the form of ATP and NADPH. In this way, these photosynthetic pigments are related to the rate of $A$, which at this same phenological stage is reduced due to the increasing doses. It is important to note that both chlorophylls play a different role in plant metabolism; chlorophyll $b$ is an accessory pigment that, together with carotenoids, helps in the photoprotection of chlorophyll $a$, maximizing the energy absorption that effectively acts in photochemical reactions (Gill and Tuteja, 2010).

This absence of difference in the other phenological stages for the levels of photosynthetic pigments is in agreement with the study that evaluated the tolerance to salinity with cherry tomatoes, where it was also observed a reduction of $A$ due to $g s$, due to the addition of silicon in cherry tomato (Haghighi and Pessarakli, 2013).

The nutrient that makes up the chlorophyll molecule is magnesium, which is responsible for enzymatic activation. The ratio of magnesium and calcium influences the process in the soil and the plant, altering the absorption of other elements. It can thus influence the growth and development of the crop. Calcium has low mobility in plants, especially in leaves (Araújo et al., 2015).

There was an influence of interaction between tomato hybrids and calcium silicate doses on the SPAD index only at 58 DAT (Figure 3E). For the other phenological stages, the factors were studied in isolation, with differences being observed only for doses of calcium silicate (Figure 3).
This difference between the studied phenological stages shows that in the stages of full flowering and fruiting, there was an increase in the values of the SPAD index compared to the other stages. In response to this increase in the values of the SPAD index throughout the crop cycle, there was an increase in the photosynthetic capacity of the plants, which is due to the content of ribulose-1,5-bisphosphate carboxylase/oxygenase (Rubisco) (Echer et al., 2020).

The observed difference of $A$ between hybrids in full fruiting stage at 78 DAT may have an impact on increased fruit productivity, thus demonstrating that the hybrid Natália, due to its genetic traits, directly influences its metabolism, having a greater capacity to perform photosynthesis, with a smaller $C i$ in intercellular spaces and a larger WUE.

Table 3. Content of chlorophyll $a, b$, and total at 17 and 78 DAT in leaves of two tomato hybrids

\begin{tabular}{cccc}
\hline \multicolumn{3}{c}{$* * 17$ DAT } \\
\hline Hybrids & $\begin{array}{c}\text { Chlorophyll } a \\
\mathrm{mg} \mathrm{g}^{-1}\end{array}$ & $\begin{array}{c}\text { Chlorophyll } b \\
\mathrm{mg} \mathrm{g}^{-1}\end{array}$ & $\begin{array}{c}\text { Total chlorophyll } \\
\mathrm{mg} \mathrm{g}^{-1}\end{array}$ \\
\hline Ivety & 0.1491 & 0.0499 & 0.1991 \\
Natália & 0.1547 & 0.0421 & 0.1968 \\
\hline CV \% & 22.65 & 44.50 & 23.50 \\
Đ & 0.0077 & 0.0046 & 0.0104 \\
\hline \multicolumn{4}{c}{78 DAT } \\
\hline \multirow{2}{*}{ Hybrids } & Chlorophyll $a$ & Chlorophyll $b$ & Total chlorophyll \\
\cline { 2 - 4 } & $\mathrm{mg} \mathrm{g}^{-1}$ & mg g & mg g \\
\hline Ivety & 0.1480 & 0.0856 & 0.2337 \\
Natália & 0.1303 & 0.0709 & 0.2012 \\
\hline CV \% & 31.95 & 29.23 & 29.42 \\
$Ð$ & 0.0099 & 0.0051 & 0.0143 \\
\hline
\end{tabular}

* Significant at $5 \%$ probability by the $\mathrm{F}$ test. ** Phenological stages.

\section{Conclusions}

At 17 DAT, no difference was observed for gas exchange variables, nor photosynthetic pigments, showing a linear increase only for the SPAD index.

Calcium silicate reduced the net $\mathrm{CO}_{2}$ assimilation rate, stomatal conductance, leaf transpiration, instant carboxylation efficiency, contents of chlorophyll $a, b$, and total, at full bloom stage at 58 DAT.

At 78 DAT, the hybrid Natália showed higher rates of net $\mathrm{CO}_{2}$ assimilation, water-use efficiency, intrinsic water-use efficiency, instant carboxylation efficiency. The hybrid Ivety was superior only for the internal concentration of $\mathrm{CO}_{2}$ and SPAD index, with no difference between the hybrids for photosynthetic pigments.

\section{Acknowledgments}

To the Western Paraná State University and the Graduate Program in Agronomy, for the opportunity to 
carry out the course. To CAPES, for the granting of the scholarship. To Sakata for donating seeds. To Agronelli for donating calcium silicate.

\section{Bibliographic References}

Abdelaal, K.A.A., Mazrou, Y.S.A., Hafez, Y.M., 2020. Silicon Foliar Application Mitigates Salt Stress in Sweet Pepper Plants by Enhancing Water Status, Photosynthesis, Antioxidant Enzyme Activity and Fruit Yield. Plants, 9(6), 733. DOI: https://doi.org/10.3390/plants9060733.

Adams, W.W., Stewart, J.J., Cohu, C.M., Muller, O., DemmigAdams, B., 2016. Habitat temperature and precipitation of Arabidopsis thaliana ecotypes determine the response of foliar vasculature, photosynthesis, and transpiration to growth temperature. Frontiers in Plant Science, 7(1), 1-18. DOI: https://doi.org/10.3389/fpls.2016.01026.

Alvares, C.A., Stape, J.L., Sentelhas, P.C., Gonçalves, J.L.M., Sparovek, G., 2013. Koppen's climate classification map for Brazil. Meteorologische Zeitschrift, 22(6), 711-728. DOI: https://doi.org/10.1127/0941-2948/2013/0507.

Araújo, H.S., Cardoso, A.I.I., Oliveira Júnior, M.X., Magro, F.O., 2015. Teores e extração de macronutrientes em abobrinha-de-moita em função de doses de potássio em cobertura. Revista Brasileira de Ciências Agrárias, 10(3), 389395. DOI: https://doi.org/10.5039/agraria.v10i3a4937.

Cruz, C.D., 2013. Genes: a software package for analysis in experimental statistics and quantitative genetics. Acta Scientiarum Agronomy, 35(3), 271-276. DOI: https://doi.org/10.4025/actasciagron.v35i3.21251.

Dalastra, G.M., Echer, M.M., Coutinho, P.W.R., Klosowski, E.S., 2018. Características produtivas de cultivares de tomateiro italiano em função de tipos de poda. Scientia Agraria Paranaensis, 17(4), 398-404.

Driever, S.M., Lawson, T., Andralojc, P.J., Raines, C.A., Parry, M.A.J., 2014. Natural variation in photosynthetic capacity, growth, and yield in 64 field-grown wheat genotypes. Journal of Experimental Botany, 65(17), 4959-4973. DOI: https://doi.org/10.1093/jxb/eru253.

Echer, M.M., Guimarães, V.F., Inagaki, A.M., Dalastra, G.M., Hachmann, T.L., 2020. Photosynthetic pigments and gas exchange in red and green cabbage under no-tillage and conventional systems. Revista Ciência Agronômica, 51(2), 110. DOI: https://doi.org/10.5935/1806-6690.20200037.

Ehleringer, J., Björkman, O., 1977. Quantum yields for $\mathrm{CO}_{2}$ uptake in $\mathrm{C} 3$ and $\mathrm{C} 4$ plants: dependence on temperature, $\mathrm{CO}_{2}$, and $\mathrm{O}_{2}$ concentration. Plant Physiology, 59(1), 86-90. DOI: https://doi.org/10.1104/pp.59.1.86.

Ferraz, R.L.S., Melo, A.S., Suassuna, J.F., Brito, M.E.B., Fernandes, P.D., Nunes Junior, E.S., 2012. Trocas gasosas e eficiência fotossintética em ecotipos de feijoeiro cultivados no semiárido. Pesquisa Agropecuária Tropical, 42(2), 181-188. DOI: https://doi.org/10.1590/S1983-40632012000200010.

Gill, S.S., Tuteja, N., 2010. Reactive oxygen species and antioxidant machinery in abiotic stress tolerance in crop plants.
Plant Physiology and Biochemistry, 48(12), 909-930. DOI: https://doi.org/10.1016/j.plaphy.2010.08.016.

Haghighi, M., Pessarakli, M., 2013. Influence of silicon and nano-silicon on salinity tolerance of cherry tomatoes (Solanum lycopersicum L.) at early growth stage. Scientia Horticulturae, 161 , 111-117.

DOI:

https://doi.org/10.1016/j.scienta.2013.06.034.

Jadoski, S.O., Klar, A.E., Salvador, E.D., 2005. Relações hídricas e fisiológicas em plantas de pimentão ao longo de um dia. Ambiência, 1(1), 11-19.

Kirschbaum, M.U.F., 1994. The sensitivity of C3 photosynthesis to increasing $\mathrm{CO}_{2}$ concentration: a theoretical analysis of its dependence on temperature and background $\mathrm{CO}_{2}$ concentration. Plant, Cell \& Environment, 17(6), 747-754. DOI: https://doi.org/10.1111/j.1365-3040.1994.tb00167.x.

Kusvuran, S., 2012. Effects of drought and salt stresses on growth, stomatal conductance, leaf water and osmotic potentials of melon genotypes (Cucumis melo L.). African Journal of Agricultural Research, 7(5), 775-781. DOI: https://doi.org/10.5897/AJAR11.1783.

Lana, R.M.Q., Korndorfer, G.H., Junior, L.A., Silva, A.F., Lana, A.M., 2003. Efeito do silicato de cálcio sobre a produtividade e acumulação de silício no tomateiro. Bioscience Journal, 19(2), 15-20.

Lichtenthaler, H.K., 1987. Chlorophyll and carotenoids: pigments of photosynthetic biomembranes. Methods in

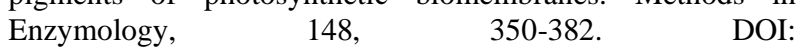
https://doi.org/10.1016/0076-6879(87)48036-1.

Marodin, J.C., Resende, J.T., Morales, R.G., Silva, M.L., Galvão, A.G., Zanin, D.S., 2014. Yield of tomato fruits in relation to silicon sources and rates. Horticultura Brasileira, $32(2)$, 220-224. DOI: https://doi.org/10.1590/S010205362014000200018 .

Murillo-Amador, B., Yamaguchi, T., Rueda-Puente, E., ÁvilaSerrano, N., García-Hernádez, J.L., López-Aguilar, R., TroyoDiéguez, E., Nieto-Garibay, A., 2007. Influence of calcium silicate on growth, physiological parameters and mineral nutrition in two legume species under salt stress. Journal of Agronomy and Crop Science, 193(6), 413-421. DOI: https://doi.org/10.1111/j.1439-037X.2007.00273.x.

Parveen, N., Ashraf, M., 2010. Role of silicon in mitigating the adverse effects of salt stress on growth and photosynthetic attributes of two maize (Zea mays L.) cultivars grown hydroponically. Pakistan Journal of Botany, 42(3), 1675-1684.

Rocha, M.R.L., Coutinho, P.W.R., Abade, M.T.R., Inagaki, A.M., Cadorin, D.A., Hoespers, L.M.L., 2019. Morfofisiologia de plantas de couve manteiga sob concentrações de húmus líquido. Revista de Ciências Agroveterinárias, 18(4), 438-443. DOI: https://doi.org/10.5965/223811711842019438.

Rodrigues, F.A., Oliveira, L.A., Korndörfer, A.P., Korndörfer, G.H., 2011. Silício: um elemento benéfico e importante para as plantas. Informações Agronômicas, 134(1), 14-20.

Siddiqui, M.H., Al-Whaibi, M.H., Faisal, M., Al Sahli, A., 2014. Nano-silicon dioxide mitigates the adverse effects of salt stress on Cucubita pepo L. Environmental Toxicology and 
Chemistry, 33(11), 2429-2437. DOI https://doi.org/10.1002/etc.2697.

Sims, D.A., Gamon, J.A., 2002. Relationships between leaf pigment content and spectral reflectance across a wide range of species, leaf structures and developmental stages. Remote Sensing of Environment, 81(1), 337-354. DOI: https://doi.org/10.1016/S0034-4257(02)00010-X.
Taiz, L., Zeiger, E., Moller, I.M., Murphy, A., 2017. Plant Physiology and Development, sixth ed. Sinauer Associates, Sunderland.

Zeist, A.R., Resende, J.T.V., Faria, M.V., Gabriel, A., Adriano, E., Lima Filho, R.B., 2018. Photosynthetic characteristics in species and interspecific hybrids of tomato. Horticultura Brasileira, 36(3), 362-370. DOI: https://doi.org/10.1590/s0102053620180313 . 